\title{
ANGON JAWI: ETNOGRAFI SUMBER PENDAPATAN ALTERNATIF PETANI KARET DI DESA BATU GODANG, KECAMATAN ANGKOLA SANGKUNUR
}

\author{
Ari Kamandanu ${ }^{1}$, Ade Ikhsan Kamil ${ }^{2}$ \\ 1,2 Program Studi Antropologi, Universitas Malikussaleh Lhokseumawe \\ Aceh-Indonesia
}

Korespondensi: ade.ikhsan.kamill@unimal.ac.id

\begin{abstract}
Abstrak: Artikel ini berfokus pada upaya proses pemenuhan kebutuhan ekonomi petani karet melalui Angon Jawi di Batu Godang, Kecamatan Angkola Sangkunur. Artinya, artikel ini berusaha untuk mendeskripsikan secara mendalam mengapa petani karet memilih menjadi buruh angon jawi untuk dijadikan sumber ekonomi tambahan dan bagaimana proses pemenuhan kebutuhan ekonomi melalui proses angon jawi. Dalam penelitian ini penulis menggunakan metodologi penelitian kualitatif dengan pendekatan etnografi. Teknik pengumpulan data menggunakan observasi partisipatif, wawancara dan studi dokumen. Hasil penelitian ini menunjukkan bahwa ada beberapa alasan yang menyebabkan petani karet memilih angon jawi menjadi sumber pendapatan alternatif demi pemenuhan kebutuhan keluarga yaitu 1) lokasi lahan yang berdekatan dengan perkebunan karet milik PTPN III yang menguntungkan para petani karet menjadi buruh angon jawi sebagai sumber pendapatan tambahan, 2) Minimnya modal menjadi buruh angon jawi, 3) Resiko pekerjaan yang minim. 4) Waktu bekerja yang hanya setengah hari dan tidak mengikat kepala keluarga.
\end{abstract}

Kata Kunci: Angon Jawi, Petani Karet, Sumber Pendapatan Alternatif, Etnografi 


\section{A. Pendahuluan}

Indonesia merupakan negara yang memiliki potensi pertanian yang baik. Salah satu produk pertanian tropika indonesia yang berpotensi menjadi andalan adalah produk pertanian segar dalam bentuk buah-buahan dan sayuran. Namun potensi tersebut tidak dimanfaatkan walaupun Indonesia memiliki potensi yang besar dan sumberdaya alam yang melimpah (FDS, 2019). Data dari kementerian pertanian pada tahun 2006 memperlihatkan bahwa sebesar 192 juta Ha yang terbagi atas 123 juta Ha merupakan kawasan budidaya dan 67 juta Ha merupakan kawasan lindung. Luasnya areal berpotensi sebagai areal pertanian yang meliputi lahan basah dan kering. Di sisi lain, jumlah luasan lahan, hutan, sungai, rawa, dan danau serta curah hujan yang tinggi sepanjang tahun berpotensi untuk pemenuhan kebutuhan apabila dikelola dengan baik.

Penggunaan lahan untuk tumbuhan tropika seperti karet sudah lama menjadi trend dalam pengelolaan lahan masyarakat di indonesia. Dalam catatan Dove (1994) via Kamil (2016) bahwa karet menjadi komoditas transformatif kehidupan masyarakat Dayak di Kalimantan dalam hal cara kerja, kepemilikan tanah, relasi terhadap tanah, input tenaga kerja dan distribusi hasil yang diusahakan. Karet memiliki masa keemasan dengan total produksi mencapai 1 ton per hektar (Kementerian Perindustrian). Namun saat ini, harga karet kian hari kian menurun hingga mencapai $4.500 / \mathrm{kg}$ sehingga membuat petani karet memutar otak untuk memenuhi kebutuhan ekonomi sebagai sumber penghasilan tambahan. Kondisi tersebut menyebabkan banyak petani karet yang masih hidup di bawah garis kemiskinan dengan tingkat kesehatan yang ala kadarnya karena kehidupan mereka banyak di daerah terpencil (Munir, 2007).

Seperti yang terjadi pada petani di Batu Godang yang terletak di Kecamatan Angkola Sangkunur Kabupaten Tapanuli Selatan yang hampir 90\% nya sebagai petani karet. Harga karet yang kian menurun berakibat terganggunya etika subsistensi kehidupan mereka yang berakibat pada pilihan untuk mencari penghasilan lain diluar dari sumber utama mata yaitu petani karet. Bahkan beberapa petani karet ada yang beralih profesi dengan menjadi wiraswasta dengan cara menjual ladang sebagai modal usaha. Selain itu, ada juga yang mempertahankan karetnya dan memilih menjadi buruh angon sebagai pekerjaan 
sampingan dengan merawat lembu pemodal hingga hari penjualan tiba. Angon jawi merupakan kegiatan menggembala dan memelihara ternak milik orang lain. Hewan ternak yang di gembala adalah kambing dan lembu di lahan milik PTPN III dengan memanfaatkan rumput di bawah pohon karet dan pendirian kandang di lahan PTPN.

Studi terkait dengan etika subsistensi menjadi salah satu core study dari fenomena ekonomi dan kebudayaan yang sering dikaji oleh para ilmuan sosialbudaya. Awalnya antropologi ekonomi muncul sebagai sebuah bidang kajian yang mempusatkan kajiannya kepada gejala ekonomi masyarakat dalam arti yang substansial yaitu ekonomi sebagai usaha manusia dalam pemenuhan kebutuhan hidup (Sjafri, dkk. 2001:4-16). Diantara banyak pendekatan dalam bidang kajian antropologi ekonomi, bagi penulis, studi terkait dengan sumber pendapatan alternatif masuk dalam secuil dari studi besar yang sudah dimulai oleh para pemikir dari sistem ekonomi personalisme seperti Eric R. Wolf (1966;1969), Samuel L Popkin (!979) dan James C Scott (1983), dan Davies (1973) yang mana mereka memusatkan perhatian studinya terhadap kehidupan petani kecil (peasant) dengan tidak menggunakan analisis material determinan dari Marx (Sjafrie, dkk. 2002, 31).

Berdasarkan kajian yang telah lama dimulai oleh Scot (1983) terkait dengan upaya petani kecil yang mendahulukan selamat dalam kehidupan harmonisnya serta rasionalitas ekonomi dari Samuel L Popkin (1979) yang memiliki strategi jangka panjang dalam hitung untung rugi, maka kajian ini ingin mengkompilasikan upaya yang dilakukan oleh petani karet di Desa Batu Godang yang memiliki strategi untuk mencari penghasilan tambahan melalui angon jawi sebagai upaya untuk menghindari batas subsistem ekonomi mereka.

\section{B. Metode}

Penelitian ini merupakan penelitian kualitatif yang berfokus pada proses upaya menghasilkan data deskriptif yang berasal dari pengamatan orang-orang sebagai subyek penelitian (Meleong, 2006, 2011). Lokasi penelitian bertempat di Desa Batu Godang Kecamatan Angkola Sangkunur Kabupaten Tapanuli Selatan. Pemilihan lokasi ini karena di desa ini hampir seluruh masyarakat berprofesi sebagai petani karet. Dengan kondisi karet yang tidak mungkin memenuhi kebutuhan sehari-hari, maka petani karet memilih berprofesi sebagai angon jawi 
sebagai upaya pemenuhan kebutuhan. Selain itu, kondisi rumput sangat banyak dan lahan yang luas berdekatan dengan lahan PTPN III sehingga pemilik modal memilih Desa Batu Godang sebagai lokasi ternak lembunya. Dalam rangka untuk mendapatkan data terkait dengan profil petani karet serta deskripsi Angon Jawi, penulis menggunakan observasi partisipasi dan wawancara mendalam sebagai teknik pengumpulan data. Proses analisis data dalam tulisan ini tidak saja dilakukan setelah semua data terkumpul, namun proses analisis telah dimulai sejak penulis turun ke lapangan pada tahun 2020 sampai dengan Januari tahun 2021.

\section{Pembahasan}

Desa Batu Godang merupakan sebuah desa yang terletak di Kecamatan Angkola Sangkunur, Tapanuli Selatan, Sumatera Utara, Indonesia. Letak Desa Batu Godang dapat di katakan jauh dari pusat pemerintahan dan jauh dari pusat Kesehatan, jarak tempuh yang di butuhkan dari Desa Batu Godang menuju Kantor Camat Angkola Sangkunur berkisar 20 KM, atau membutuhkan waktu 40 menit-1 jam perjalanan menggunakan sepeda motor, sedangkan jarak tempuh dari Desa Batu Godang menuju Pusskesmas Angkola sangkunur bejarak $18 \mathrm{KM}$, atau dapat di tempuh selama 40 menit perjalanan menggunakan sepeda motor.

Menurut informasi yang peneliti dapat dari sekretaris desa, belum ada catatan pasti tentang awal mula berdirinya Desa Batu Godang, namun jika di tinjau dari garis keturunan masyarakat Desa Batu Godang ini ada yang telah mencapai keturunan ketiga, yang apabila di Tarik garis perhitungan maka sejak tahun 1920an Desa Batu Godang telah di huni oleh masyarakat. Selain itu pada masyarakat desa Batu Godang masih terdapat keturunan portugis yang di percaya bahwa mereka adalah keturunan portugis yang menikah dengan masyarakat lokal pada masa penjajahan dan menetap di Desa Batu Godang. Saat ini jumlah penduduk di Desa Batu Godang sebanyak 2.10 Jiwa yang terdiri atas 682 KK dimana 1.449 jiwa berjenis kelamin laki-laki dan 1.261 jiwa berjenis kelamin perempuan.

Desa Batu Godang memiliki potensi sumber daya alam (SDA) yang sangat baik hal ini di dikarenakan letak geografisnya yang berada di kontur tanah perbukitan dan di tambah lagi sebagian besar Desa Batu Godang berbatasan langsung dengan lahan PTPN III Persero. Lahan PTPN III di sekitaran Desa Batu Godang di tanami pohon karet yang secara otomatis sama dengan sebagian besar lahan pertanian 
masyarakat setempat, memiliki lahan karet yang berdampingan memiliki beberapa keuntungan, antara lain kondisi tanah yang subur karena proses pemupukan pada lahan PTPN rutin di lakukan, secara otomatis tanah yang ada di dekat lahan PTPN juga ikut subur karena unsur hara dari pupuk tersebut akan menyebar ke lahan milik masyarakat. Kondisi inilah yang kemudian di manfaatkan oleh masyarakat Desa Batu Godang dengan menanam karet di lahan-lahan pertanian mereka. Sebahagian besar seluruh masyarakat Batu Godang berprofesi sebagai petani karet, selebihnya ada yang berprofesi sebagai pedagang, ASN (Aparatur Sipil Negara) dan sisanya sebagai buruh.

Sebagai salah satu desa dengan tingkat keragaman yang tinggi, Desa Batu Godang memiliki wadah yang menyatukan mereka dalam berbagai kegiatan sosial dan budaya seperti perwiritan yasin ibu-ibu dan bapak-bapak yang rutin dilakukan seminggu sekali, gotong royong dalam kebutuhan sosial-keagamaan, marpokat karejo (kegiatan pembagian tugas bagi para pemuda-pemudi dalam perayaan pernikahan) serta rewang.

\section{Jenis Sumber Pendapatan Alternatif Petani Karet di Batu Godang}

Hidup di bawah tekanan ekonomi yang sulit karena harga getah karet yang terus menurun dan tak kunjung naik, memaksa masyarakat Desa Batu Godang untuk mencari pekerjaan sampingan dalam memenuhi kebutuhan pokok sehari- hari. Adapun jenis-jenis pekerjaan sampingan yang di lakukan masyarakat desa Batu Godang yaitu :

1. Membuka warung kopi, di manfaatkan masyarakat sebagai sumber pendapatan alternatif. Namun tidak dalam jumlah yang banyak, hanya ada 1 sampai 2 warung kopi di setiap dusunnya, jika di total jumlah warung kopi yang ada di desa Batu Godang sebanyak 10-12 warung kopi.

2. Membuka warung sembako, masyarakat menjadikannya sebagai sumber pendapatan alternatif karena menyediakan berbagai macam jenis kebutuhan pokok. Masyarakat Desa Batu Godang berbelanja beberapa kebutuhan di warung, kondisi ini tentu akan memberi keuntungan bagi masyarakat yang memiliki warung sembako. 
3. Buruh Angkat di Pasar, karena Desa Batu Godang memiliki fasilitas desa berupa pasar di tengah desa yang beroprasi setiap hari sabtu. pedagang yang berdagang berasal dari luar daerah Batu Godang. Biasanya dari kecamatan Batangtoru dan Padang Sidempuan. Pada hari sabtu masyarakat desa Batu Godang ada yang bekerja sebagai buruh angkat di pasar. Dalam sehari mereka bisa mendapatkan 50 sampai dengan 100 ribu rupiah dalam kurun waktu seminggu sekali.

4. Buruh Angon Jawi merupakan pekerjaan menggembala lembu milik orang lain yang kemudian mendapat upah atau bagian dari lembu yang mereka gembala. Pemilik lembu merupakan masyarakat yang berasal dari luar Desa Batu Godang, yaitu berasal dari kecamatan Batangtoru. Pemilik lembu merupakan pekerja swasta, mereka bukan PNS ataupun karyawan PTPN III Persero, namun mereka adalah orang yang berani meminjam uang ke Bank, artinya orang yang memiliki cukup modal. Mereka percaya, berbisnis lembu di serahkan kepada buruh angon untuk di besarkan hingga masa penjualan tiba.

Dalam proses angon jawi tentunya memiliki beberapa proses tahapan yang harus di lakukan oleh pemilik modal/toke dan buruh angon, Adapun beberapa tahapan tersebut adalah :

a) Proses pencarian buruh Angon yang di lakukan di suatu daerah, bertujuan untuk di jadikan lokasi angon jawi dan mencari orang yang bersedia bekerja sama.

b) Perjanjian di lakukan untuk membuat kesepakatan, artinya aturan yang sudah di sepakati selama angon jawi berupa upah yang di tawarkan dan resiko kerugian selama proses angon jawi ini di lakukan.

c) Membuat kesepakatan terkait hak dan kewajiban buruh angon, antara lain yaitu: pertama, hak buruh angon adalah dapat memilih anak yang dilahirkan, berhak meminjam uang, serta meminta perlengkapan pendukung, berhak meminta gaji jika jatuh tempo. Kedua, kewajiban buruh angon adalah merawat, membersihkan, mengontrol kesehatan lembu, melaporkan kepada pemilik jika hewan tersebut sakit 
d) Penyerahan lembu atau proses mengantar lembu untuk di angon kepada buruh angon akan di catat tanggal penyerahannya supaya memudahkan saat menghitung hasil serta pembagian hasilnya. Pada saat penyerahan selesai, barulah semua perjanjian beserta hak dan kewajiban mulai berlaku.

e) Sistem angon yang diterapkan di Desa Batu Godang adalah melepaskan lembu ke alam liar, terhitung dari siang hingga sore hari. Para buruh angon mulai melepaskan lembu mereka mulai pukul 14.00 hingga pukul 17.30 sampai 18.00. Lembu berada di alam liar untuk mencari makan sedangkan buruh angon akan mengikuti atau memantau lembu tersebut. Selain itu buruh menerapkan sistem arit atau mengambil rumput untuk pakan lembu. Rumput tersebut di berikan pada saat malam dan pagi tiba, agar lembu yang dia rawat lebih cepat gemuk dan sehat. Sedangkan mengarit rumput dilakukan satu atau dua bulan masa penjualan bertujuan agar lembu terlihat gemuk. karna semakin gemuk lembu yang di angon maka semakin tinggi pula harga jualnya. Dengan hal ini lembu tersebut akan menambah hasil bagian buruh angon.

Lembu yang di angon di Desa Batu Godang umumnya adalah jenis lembu lokal, akan tetapi ada beberapa varian jenis lambu lain seperti Brahman, limosin, Bali, dan Aceh. Akan tetapi jenis-jenis lembu ini tidak lagi asli melainkan hasil dari perkawinan silang secara alami yaitu si mental, mongol, brahman, dan lembu lokal. Dalam proses angon jawi biasanya akan terjadi konflik antara pihak buruh angon dengan PTPN.III ataupun antara buruh angon dengan masyarakat. Hal ini disebabkan antara lain: lembu yang merusak atau menjatuhkan getah hasil sadapan, lembu masuk ke dalam areal pembibitan milik PTPN III, Lembu masuk ke areal perkebunan masyarakat.

\section{Proses Pemenuhan Perekonomian Petani Karet melalui Angon Jawi}

Para petani karet di Desa Batu Godang mencari pekerjaan sampingan untuk di jadikan sebagai sumber pendapatan tambahan dengan memilih menjadi buruh angon untuk memenuhi kebutuhan. Proses dan modal yang di butuhkan relatif mudah dan murah, hasil dari menjadi buruh angon di anggap sangat membantu perekonomian sehari-hari petani karet. Adapun proses pemenuhan perekonomian petani karet melalui angon jawiadalah sebagai berikut: 
(1) Menjadi Buruh Angon Dengan Sistem Gaji Bulanan yaitu besar pendapatan buruh angon tergantung jumlah lembu yang di angon, besaran gaji dalam setiap bulanan berkisar 70-80 ribu rupiah. Jumlah lembu yang di angon Di Desa Batu Godang rata-rata berjumlah 20-30 ekor lembu, jika di hitung dari 20 ekor lembu maka buruh angon menerima pendapatan dengan perhitungan $20 \times 70.000=1.400 .000$ ribu rupiah setiap bulannya.

(2) Sistem bagi hasil ini terbagi menjadi dua yaitu pertama, bagi hasil lembu jantan keuntungan dari hasil penjualan akan di bagi menjadi dua bagian, satu bagian untuk si pemilik modal dan satu bagian lagi untuk buruh angon. Ini dilakukan dengan cara mengurangi hasil penjualan dengan harga modal awal, kemudian sisa dari hasil pembagian akan di bagi mejadi ke dalam dua bagian, satu bagian untuk pemilik modal dan satu bagian lagi untuk buruh angon. Kedua, sistem pembagian lembu betina dalam proses angon jawi betina buruh angon harus menunggu jawi tersebut melahirkan dengan waktu yang harus di tunggu buruh angon apabila lembu betina yang di berikan oleh pemilik modal masih dere (belum pernah melahirkan) berumur satu tahun maka buruh angon harus menunggu jawi tersebut berumur dua tahun, setelah berumur dua tahun barulah jawi tersebut bisa mengandung.

(3) Bagi Hasil Dengan Metode 13 : 1 adalah dari setiap 13 ekor lembu yang di angon maka satu ekor lembu akan menjadi bagian untuk buruh angon dan 12 ekor lembu lainnya menjadi bagian utnuk pemilik modal. Biasanya sistem ini hanya di gunakan pada buruh angon yang menangon jawi dengan jumlah sangat banyak yang biasanya mengangon lebih dari 50 ekor jawi. Biasanya lembu yang menjadi bagian untuk buruh angon adalah lembu yang memiliki ukuran sedang tidak yang paling besar dan tidak pula yang paling kecil.

(4) Menjadi Agen Saat Masa Penjualan Idul Adha yaitu keuntungan dari proses bagi hasil dari lembu yang di angon, para buruh angon biasanya memanfaatkan momen masa penjualan lembu pada saat mendekati Idul Adha menjadi agen penjual lembu. Ada dua tipe agen lembu di Desa Batu godang yaitu sebagai penunjuk jalan dan menjadi agen dengan sistem panjar. 


\section{Hubungan Konsep Etika Subsistensi James C. Scott dengan Angon Jawi}

Dalam buku moral ekonomi petani Scott menjelaskan bahwa perekonomian buruh pabrik atau karyawan sangat berbeda jauh dengan konsep ekonomi petani. Buruh pabrik atau karyawan mereka sudah mapan dengan gaji dan tanggungan yang di berikan sehingga para buruh atau karyawan tidak perlu lagi memutar kepala untuk mencukupi kebutuhan ekonomi keluarga. Berbeda dengan sistem ekonomi petani dengan segala keterbatasan yang di miliki oleh petani. Kondisi ini memaksa petani harus memutar otak lebih keras untuk memenuhi kebutuhan ekonominya dan mencari sumber pendapatan tambahan untuk bisa bertahan hidup. Konsep “Utamakan Keselamatan” Scott menjelaskan berada di garis kemiskinan misalnya gagal panen yang sangat menyulitkan kehidupan petani sehingga harus mencari pendapatan alternatif.

Hal ini berkaitan dengan konsep Ekonomi Subtantif dengan angon jawi yang di lakukan oleh petani karet di Desa Batu Godang yaitu kegiatan angon jawi yang di lakukan petani karet di Desa Batu Godang. Bertahan hidup di tengah merosotnya harga karet yang tidak kunjung naik dan di perparah dengan harga sembako yang kian hari kian melambung naik. Menjadi buruh angon, para petani karet di Desa Batu Godang mendapat sumber pendapatan tambahan. Kondisi ini tentu sejalan dengan konsep dahulukan selamat yang di jelaskan oleh James C. Scott dimana kondisi petani yang kehidupannya sangat dekat dengan garis kemiskinan harus mencari cara atau mencari sumber penghasilan untuk bisa tetap bertahan.

Relasi Sosial-Produksi

Relasi produksi sosial dan teknis: termasuk relasi properti, kekuasaan, dan kontrol yang mengatur aset produktif masyarakat, relasi dan bentuk kerja kooperatif dari asosiasi, relasi antara orang-orang dan objek-objek pekerjaan mereka, serta relasi antara kelas-kelas sosial.

1. Patron- Client

Menurut Scott patron klien merupakan hubungan timbal balik antara dua orang (yang memiliki perbedaan status sosial ekonomi) yang dijalin secara khusus atau dengan dasar saling menguntungkan, serta saling memberi dan menerima, dimana status sosial yang lebih tinggi (patron) dengan adanya sumber daya yang dimiliki. Praktek angon jawi di Desa Batu Godang merupakan suatu contoh patron- 
clien, dimana pemodal adalah orang yang bestatus sosial ekonomi lebih tinggi sebagai Proton dan buruh angon yang beeperan sebagai clinet. pemilik modal mendapat keuntungan dari hasil penjualan begtiu juga buruh angon mendapat keuntungan atau upah yang dapat memenuhi kebutuhan ekonomi keluarganya.

2. Hak dan kewajiban

Dalam skrispi angon jawi yang menjadi hak nya adalah upah yang di terima oleh angon jawi sedangkan kewajiban adalah segala sesuatu yang harus di lakukan dalam pekerjaan yang menjadi tanggung jawabnya.

3. Aktor

Dalam skripsi ini yang menjadi actor adalah pemilik sapi dan juga buruh yang merawat dan menjaga sapi tersebut, dan orang-orang sekitar yang menjadi aktor pendukung.

4. Aspek Ideologi dan Politik

Ideologi adalah Kemampuan pada rangkainan nilai yang dikandungnya dapat memenuhi serta menjamin segala aspirasi dan kehidupan manusia. Sedangkan aspek politik sebagai kondisi dinamika kehidupan yang berisi keuletan,ketangguhan dalam menghadapi dan mengatasi tantangan, ancaman, hambatan, serta gangguan yang datang dari luar maupun dari dalam. Hal inilah yang sedang di terapkan petani karet di Desa Batu Godang di sebabkan oleh harga jual getah karet yang kian hari kian menurun. Proses adaptasi dengan cara mencari sumber pendapatan alternatif untuk bertahan hidup dengan memilih menjadi buruh angon jawi sebagai upaya adaptasi. upaya adaptasi menjadi buruh angon untuk memenuhi kebutuhan ekonomi sehari-hari, sandang pangan hingga mampu menyekolahkan anak sampai ke jenjang SLTA.

\section{Penutup}

Berdasarkan hasil penelitian yang telah penulis lakukan tentang angon jawi sebagai sumber pendapatan tambahan pada masyarakat Desa Batu Godang Kecamatan Angkola Sangkunur. Maka penulis dapat menarik beberapa kesimpulan yaitu :

1. Masyarakat Desa Batu Godang adalah desa yang hampir seluruh masyarakatnya berprofesi sebagai petani karet. Di tengah merosotnya harga getah karet para petani harus bekerja sebagai buruh angon jawi untuk bisa bertahan hidup. 
2. Alasan petani karet memilih menjadi buruh angon jawi sebagai sumber pendapatan tambahan untuk mencukupi kebutuhan ekonomi keluarga adalah :

a) lokasi lahan yang berdekatan dengan perkebunan karet milik PTPN III yang menguntungkan para petani karet menjadi buruh angon jawi sebagai sumber pendapatan tambahan, karena mereka bisa memanfaat kan lahan PTPN untuk di jadikan lokasi angon jawi. Para buruh agon memanfaatkan rumput yang tumbuh di sekitaran lahan karet PTPN III sebagai pakan jawi yang mereka angon.

b) Minimnya modal menjadi buruh angon jawi. Untuk mnjadi buruh angon jawi sangat sedikit modal yang di butuhkan, karena semua modal di tanggung oleh pemilik modal. Untuk menjadi buruh angon jawi hanya perlu mencari lokasi lahan yang tepat untuk di jadikan lokasi mengangon jawi dan mencari lokasi yang tepat untuk mendirikan kandang jawi. kandang jawi biasanya di didirikan di lahan milik PTPN III. Dalam pemilihan lahan untuk mendirikan kandang buruh angon harus mencari lahan kosong yang sudah tidak ada tanaman karet, hal ini di lakukan agar tidak mengganggu para karyawan PTPN bekerja.

c) Resiko pekerjaan yang minim. Bekerja sebagai buruh angon merupakan pekerjaan yang sangat minim resiko kerugian, hal ini dikarenakan segala kerugian yang terjadi pada dalam proses angon di tanggung oleh pemilik modal, selagi kerugian itu tidak bersumber dari kesalahan dan kelalaian buruh angon maka kerugian itu di tanggung oleh pemilik modal dan tidak di beratkan kepada buruh angon, akan tetapi apabila kerugian itu berasal dari kesalahan dan kelalaian buruh angon barulah buruh angon harus bertanggung jawab.

d) Waktu bekerja yang hanya setengah hari dan tidak mengikat kepala keluarga. Kegiatan mengangon jawi di lakukan mulai pukul 14.00 atau setelah makan siang, kondisi ini sangat menguntungkan para petani yang bekerja sampingan menjadi buruh angon jawi. Setelah waktu makan siang mereka bekerja sebagai buruh angon jawi, selain wakgu kerja yang di mulai dari sinag bekerja mejadi buruh angon jawi juga tidak mengikat kepala keluarga, seluruh anggota keluarga juga bisa melakukan pekerjaan angon. Hal ini juga 
mejadi alasan mengapa petani karet memilih menjadi buruh angon, karena di saat mereka ada keperluan pada siang hari, pekerjaan angon jawi dapat di kerjakan oleh anak atau istri.

3. Pemenuhan perekonomian petani karet melalui angon jawi terbagi menjadi beberapa cara yaitu :

a) Menjadi buruh angon dengan sistem gaji bulanan tidak berbeda jauh dengan sistem gaji pada buruh pabrik, pemilik modal akan memberi gaji di setiap tanggal yang telah di sepakati. Adapun besaran gaji buruh angon jawi ratarata per ekor adalah sebesar 70-75 ribu rupiah.

b) Menjadi buruh angon jawi dengan sistem bagi hasil. Sistem bagi hasil dalam proses angon jawi terbagi menjadi 2 cara yaitu: pertama, Sistem bagi hasil lembu jantan keuntungan dari hasil penjualan akan di bagi menjadi dua bagian, satu bagian untuk si pemilik modal dan satu bagian lagi untuk buruh angon. Kedua, Sistem pembagian lembu betina dalam proses angon jawi betina buruh angon harus menunggu jawi tersebut melahirkan. Apabila lembu betina yang di berikan oleh pemilik modal masih dere (belum pernah melahirkan) berumur satu tahun maka buruh angon harus menunggu jawi berumur dua tahun, setelah berumur dua tahun barulah jawi tersebut bisa mengandung.

c) Sistem bagi hasil Dengan Metode 13:1 adalah dari setiap 13 ekor lembu yang di angon maka satu ekor lembu akan menjadi bagian untuk buruh angon dan 12 ekor lembu lainnya menjadi bagian utnuk pemilik modal. Biasanya sistem ini hanya di gunakan pada buruh angon yang menangon jawi dengan jumlah sangat banyak yang biasanya mengangon lebih dari 50 ekor jawi. Biasanya lembu yang menjadi bagian untuk buruh angon adalah lembu yang memiliki ukuran sedang tidak yang paling besar dan tidak pula yang paling kecil. 


\section{Daftar Pustaka}

Davis, William G. 1973. Social Relations in Phillipine Market. Barkeley: University of California Press.

FDS. 2019. "Sektor Pertanian di Indonesia dan Potensinya", www.fulldronesolutions.com, Online diakses tanggal 3 Desember 2019.

James C. Scott. 1985. Weapons of The Weak. New Haven: Yale University Press.

James C. Scott.1976. Moral Ekonomi Petani Pergolakan dan Subsisstensi di Asia Tenggara. LP3ES Lembaga Penelitian dan Penerangan Ekonomi dan Sosial.

Kementrian Perindustrian " Produktivitas Indonesia Kalah Dengan Malaysia dan Thailand "https://kemenperin.go.id/artikel/7341/Produktivitas-KaretNasional-Kalah-dari-Malaysia-dan-Thailand".

Meleong. 2006. Metode Penelitian Kualitatif. Bandung. PT. Remaja rosdakarya

Meleong. 2011. Metode Penelitian Kualitatif. Bandung. PT. Remaja rosdakarya

Munir, Misbahul, 2017. "Ekonomi Politik Kehidupan Petani Karet". Online (http://indonesia.tempo.com.)

Nasruddin, dkk. 2008. Kearifan Lingkungan dalam Perspektif Budaya Jawa. Jakarta: Yayasan Obor Indonesia

Popkin, Samuel L. 1979. The Rational Peasant. Barkeley: University of California Press.

Sjafri Sairin,dkk 2002. Pengantar Antropologi Ekonomi. Yogyakarta: Pusataka Pelajar.

Wolf, Eric R. 1965. Peasant. Englewood Cliffs: Prentice Hall. 